\title{
Effect of Postsymptom Application of Fungicides on Urediniospore Production by Puccinia triticina on Wheat and $P$. hemerocallidis on Daylily
}

\author{
J. W. Buck, K. Wise, and W. Dong, Department of Plant Pathology, University of Georgia, Griffin 30223
} \begin{abstract}
wheat and $P$. hemerocallidis on daylily. Plant Dis. 95:325-330.
\end{abstract}
Abstract

Buck, J. W., Wise, K., and Dong, W. 2011. Effect of postsymptom application of fungicides on urediniospore production by Puccinia triticina on duction by $P$. triticina at all collection times $(24,48$, and $72 \mathrm{~h})$ and cumulative production in both trials. No differences were observed between the QoI fungicides with $P$. triticina. The four QoI fungicides significantly reduced urediniospore production by $P$. hemerocallidis compared with the nonfungicide control, with significantly fewer urediniospores produced in the pyraclostrobin-treated lesions compared with azoxystrobin, fluoxastrobin, and trifloxystrobin. Differences in leaf morphology between daylily and wheat such as leaf thickness and waxiness may contribute to the differences observed between the two pathosystems. The significant reductions in urediniospore production by postsymptom applications of QoI fungicides, combined with their known fungistatic properties, suggest that these chemistries would be useful for reducing the spread of viable inoculum to noninfested plants.
Fungicides are an important management tool for many rust diseases. Although host resistance is the preferred management strategy for rust diseases of agronomic crops, fungicides are needed to manage these diseases when new races of rust fungi overcome host resistance. Important recent examples include the development of race Ug99 of Puccinia graminis f. sp. tritici causing stem rust disease of wheat (25) and the Rpp9-virulent race of $P$. polysora causing southern rust disease on corn (9). Fungicides are also necessary to manage rust diseases when genetic resistance is not commercially available or does not reduce disease levels to economically acceptable levels, as is the case with soybean rust (15) and rusts of ornamental plants (4).

Although most fungicides are recommended and most efficacious when used prior to symptom development, in the case of rust diseases, applications are often made after symptoms are observed (postsymptom). Postsymptom fungicide applications would be to lesions over a range of developmental stages from preerumpant infection sites to older, senescing lesions. Fungicides could then act upon either spore viability or spore production, as well as provide protection for noninfected host tissue. Postsymptom applications of propiconazole and azoxystrobin reduced $P$. graminis urediniospore production per pustule on perennial ryegrass by 73 and $95 \%$, respectively (24). Sundin et al. (31) reported that winter wheat seed treated with the systemic fungicides difenoconazole or triadimenol suppressed sporulation levels of $P$. recondita in wheat to 10 and $50 \%$, respectively, of the nontreated control. The effects of fungicides on reducing spore production have also been reported in other plant pathogen systems besides rusts $(16,26,27,34)$. For

\section{Corresponding author: J. W. Buck, E-mail: jwbuck@uga.edu}

Current address of K. Wise: Department of Botany and Plant Pathology, Purdue University, West Lafayette, IN.

Accepted for publication 18 November 2010.

doi:10.1094/PDIS-09-10-0646

(C) 2011 The American Phytopathological Society example, chlorothalonil reduced sporulation of Cercospora beticola on sugar beet to $51 \%$ of the control (1).

Quinone outside inhibitor (QoI) fungicides inhibit electron transport between cytochrome $\mathrm{b}$ and cytochrome $\mathrm{c} 1$ in the mitochondrial respiratory chain (3). A subset of QoI fungicides, commonly referred to as strobilurin fungicides, originate from strobilurin A, which is a secondary metabolite produced by the basidiomycete Strobilurus tenacellus $(2,3)$. These fungicides are strongly inhibitory to germination of fungal spores (19), and inhibited germination of urediniospores of several rust pathogens of ornamental crops after very short exposure times $(6,21)$. StarkUrnau et al. (30) observed that kresoxim-methyl, another strobilurin product, strongly inhibited sporulation of $P$. recondita on detached leaves of wheat. In contrast, no effect on sporulation of $P$. recondita on wheat was observed with a foliar application of kresoxim-methyl in greenhouse trials, presumably due to insufficient uptake of active ingredient into the leaf mesophyll (13). Azoxystrobin had a significant protective effect and curative activity against three Puccinia spp. on daylily, geranium, and sunflower (20). This fungicide is translocated acropetally within the leaves and displayed curative activity against $P$. recondita on wheat 5 days postinfection (11).

The value of fungicides for rust disease management is well known; however, the impact of fungicides on postsymptom urediniospore production in planta has not been well characterized. A quantitative understanding of the effects of fungicide applications on urediniospore production will allow for the development of better epidemic and management models (24). The objectives of this study were to compare effects of postsymptom application of fungicides representing different chemical classes on urediniospore production in planta of two species of Puccinia on widely divergent hosts. As model systems, we chose P. triticina Erikss. on wheat (Triticum aestivum L.) and $P$. hemerocallidis Thüm. on daylily (Hemerocallis sp.). Wheat leaf rust can result in significant yield losses over large geographic areas $(18,28,29)$. Currently, worldwide annual losses from leaf rust are estimated to be the equivalent of US\$2 billion (National Agricultural Statistic Service). Daylily is a popular, herbaceous perennial used as an ornamental plant throughout the United States and grown by commer- 
cial nurseries in the ground or in containers. $P$. hemerocallidis was first described in the United States in 2000 (32) and resulted in widespread losses to growers due to federal quarantine measures (33). These rusts were chosen because, although the hosts differ in economic factors and production settings, they are both rusts of monocots with similar infection cycles. Studying the impact of fungicides on urediniospore production will provide the opportunity to compare the results across species of rusts and hosts to see how applicable they would be in other monocot systems.

\section{Materials and Methods}

Pathogen and plant maintenance. $P$. hemerocallidis Grif2 (5) and a field isolate of $P$. triticina collected in Plains, GA were maintained on 'Pardon Me' daylily (Hemerocallis sp.) or 'AGS 2000' winter wheat (T. aestivum) respectively in a greenhouse with average night and day temperatures of 22 and $28^{\circ} \mathrm{C}$, respectively, under ambient light. Daylily plants were grown in Metro-Mix 400 (The Scotts Company, Marysville, $\mathrm{OH}$ ) in 3.8-liter pots and fertilized with Osmocote Plus 15-9-12 controlled-release fertilizer (The Scotts Co.). Cold stratified wheat seed were sown in 3.7-by-5.8-cm six-packs (TFI Polyform, Inc., Plymouth, MN) in Metro-Mix 360 (The Scotts Co.) for 4 to 6 weeks prior to inoculation with $P$. triticina.

Inoculum preparation. Urediniospores of each rust species were collected from actively sporulating 2- to 3-week-old pustules on maintained plants using a handheld vacuum collector. Urediniospores were enumerated using a hemacytometer and suspended in $0.001 \%$ Tween 20 (J. T. Baker, Phillipsburg, NJ) to obtain a spore suspension of approximately $1 \times 10^{5}$ urediniospores $/ \mathrm{ml}(20)$. Experimental plants were watered immediately prior to inoculation, sprayed with the prepared urediniospore suspension using a handheld sprayer until runoff, placed in plastic bags to maintain high relative humidity, and stored in the dark at $23^{\circ} \mathrm{C}(5,23)$. Bags were removed after $24 \mathrm{~h}$, and daylily and wheat plants were placed back in the greenhouse according to the experimental design.

Effect of fungicides on urediniospore production. The experiments were designed as a completely randomized block with four replications for daylily and five replications for wheat. Individual plants of each species were considered to be an experimental unit.

Approximately 2 weeks after inoculation, all urediniospores were removed from sporulating lesions on experimental plants by vacuuming lesions. This was done to observe the effect of fungicide treatment only on urediniospores produced after treatments were applied. Three to four leaves per plant were selected and marked for data collection. Fungicides were prepared using formulated commercial products at rates in Table 1 . In the first experiment, plants were treated with fungicides from five chemical groups (azoxystrobin, QoI group; chlorothalonil, broad-spectrum group; fenhexamid, hydroxyanalide group; thiophanate-methyl, benzimidazole group; or myclobutanil, demethylation inhibitor group). In the second experiment, plants were treated with one of four QoI fungicides (azoxystrobin, fluoxastrobin, pyraclostrobin, or trifloxystrobin; Table 1). Fungicides were applied to run-off using a handheld sprayer. The control for each experiment was sprayed to run-off with tap water and $0.01 \%$ Tween 20 . Treated plants were maintained on a greenhouse bench with average night and day temperatures of 22 and $26^{\circ} \mathrm{C}$, respectively. Daylily and wheat trials were not run concurrently. All experiments were conducted twice.

Data collection and analysis. At 24-h intervals for up to $96 \mathrm{~h}$ post fungicide application, urediniospores were collected from 100 to 150 lesions on the marked leaves on each plant for each experiment. Urediniospores were collected into separate, clean, 20-ml disposable scintillation vials (Fisher Scientific) using a handheld vacuum collector. Urediniospores were suspended in 1 or $2 \mathrm{ml}$ of $0.05 \%$ Tween 20 and enumerated with a hemacytometer to determine total spore production. The total number of lesions for each plant was recorded after the final urediniospore collection, and urediniospore production per lesion in each 24-h period and cumulative period ( $72 \mathrm{~h}$ for the first experiment or $96 \mathrm{~h}$ for the second experiment) was calculated. Urediniospore production was analyzed using the general linear models procedure (PROC GLM) in SAS (version 9.1; SAS Institute, Inc., Cary, NC). Treatment means were compared using Fisher's protected least significant difference test with $P=0.05$.

\section{Results}

There were significant $(P<0.05)$ trial-treatment interactions on spore production for both $P$. hemerocallidis and $P$. triticina; therefore, data from individual trials are presented separately.

Effect of fungicide class on urediniospore production by $P$. triticina. Azoxystrobin significantly reduced urediniospore production by $P$. triticina compared with the control at $48 \mathrm{~h}(26.6 \%$ of control) but not at 24,72 , or $96 \mathrm{~h}$ post treatment in one trial of the experiment (Fig. 1A). In the second trial, urediniospore production was significantly reduced by azoxystrobin at all collection times used in the other trial $(P \leq 0.0069)$ and was $9.5 \%(24 \mathrm{~h}), 12.4 \%$ (48 h), $9.1 \%(72 \mathrm{~h})$, and $16.5 \%$ (96 h) of the control (Fig. 1C). Cumulative urediniospore production was significantly reduced by azoxystrobin to $40.1 \%$ (Fig. 1B) and $11.3 \%$ of the controls in the two trials, respectively (Fig. 1B and D). Chlorothalonil, fenhexamid, myclobutanil, and thiophanate-methyl did not affect cumulative urediniospore production by $P$. triticina in either trial of the experiment.

Effect of fungicide class on urediniospore production by $P$. hemerocallidis. Azoxystrobin significantly urediniospore production of $P$. hemerocallidis at $24 \mathrm{~h}$ post application in one trial (Fig. $2 \mathrm{~A})$ and reduced urediniospore production at 24,48 , and $72 \mathrm{~h}$ post treatment in the second trial (Fig. 2D). Urediniospore production of the azoxystrobin-treated lesions was $37.6 \%(24 \mathrm{~h})$ of the control in one trial (Fig. 2A) and 32.1\% (24 h), 43.3\% (48 h), and $33.3 \%$ $(72 \mathrm{~h})$ of the control in the other trial (Fig. 2C). Azoxystrobin

Table 1. Fungicides representing five chemical classes that were evaluated for their effect on sporulation by Puccinia hemerocallidis on daylily and $P$. triticina on wheat

\begin{tabular}{|c|c|c|c|c|c|}
\hline Active ingredient & Chemical group name & Trade name & Formulation $^{\text {a }}$ & Company & $\begin{array}{c}\text { Rate } \\
\text { (a.i. g/liter) }\end{array}$ \\
\hline Fenhexamid & Hydroxyanalide & Decree & $50 \mathrm{WDG}$ & SePRO Corp., Carmel, IN & 0.60 \\
\hline Thiophanate-methyl & Benzimidazole & 3336 & $41.25 \mathrm{SC}$ & Cleary Chemical Corp., Dayton, NJ & 0.50 \\
\hline Myclobutanil & Demethylation inhibitor ${ }^{\mathrm{b}}$ & Systhane & $40 \mathrm{WSP}$ & $\begin{array}{l}\text { Dow AgroSciences Australia Limited, Frenchs Forest, } \\
\text { NSW }\end{array}$ & 0.15 \\
\hline Chlorothalonil & Broad-spectrum & Daconil Ultrex & 82.5 WDG & Syngenta Crop Protection, Inc., Greensboro, NC & 0.92 \\
\hline Azoxystrobin & $\mathrm{QoI}^{\mathrm{c}}$ & Heritage WG & $50 \mathrm{WDG}$ & Syngenta Crop Protection & 0.15 \\
\hline Fluoxastrobin & QoI & Disarm & $40.3 \mathrm{SC}$ & Arysta Lifescience, Cary, NC & 0.15 \\
\hline Pyraclostrobin & QoI & Headline & $23.4 \mathrm{EC}$ & $\begin{array}{l}\text { BASF Corporation Agricultural Products, } \\
\text { Research Triangle Park, NC }\end{array}$ & 0.15 \\
\hline Trifloxystrobin & QoI & Compass O & $50 \mathrm{WDG}$ & OHP Inc., Mainland, PA & 0.15 \\
\hline
\end{tabular}

a Percentage of active ingredients in commercial products formulated as an emulsifiable concentrate (EC), water-dispersible granules (WDG), soluble concentrate (SC), and wettable powders in water-soluble packets (WSP).

${ }^{\mathrm{b}}$ Demethylation inhibitor of sterol biosynthesis.

c Quinone outside inhibitors. 
significantly reduced cumulative urediniospore production over the 96-h collection period to $35.6 \%$ (Fig. 2B) and 37.9\% (Fig. 2D) of control in the two trials, respectively.

Myclobutanil significantly reduced urediniospore production $P$. hemerocallidis at the 24-h collection in the first trial (Fig. 2A) and both myclobutanil and fenhexamid significantly reduced urediniospore production 24,48 , and $72 \mathrm{~h}$ post treatment in the second trial (Fig. 2C). Urediniospore production of the myclobutaniltreated $P$. hemerocallidis lesions was $54.0 \%(24 \mathrm{~h})$ of the control in one trial (Fig. 2A) and 35.6\% (24 h), 46.8\% (48 h), and 32.4\% (72 h) of the water control in the second trial (Fig. 2C). Fenhexamid and myclobutanil significantly reduced cumulative urediniospore production in the second trial (Fig. 2D).

Effect of QoI fungicides on urediniospore production by $P$. triticina. Similar results were observed in both trials. All four QoI fungicides significantly reduced urediniospore production by $P$. triticina compared with the control at all collection times $(24,48$, and $72 \mathrm{~h}$ ) and cumulative production over the 72-h period in both trials (Fig. 3A and C). No significant differences in urediniospore production were observed among the QoI fungicides. Cumulative urediniospore production averaged across the four fungicides was 14.9 and $19.0 \%$ of the control in the first and second trials, respectively (Fig. 3B and D).

Effect of QoI fungicides on urediniospore production by $P$. hemerocallidis. The four QoI fungicides significantly reduced urediniospore production by $P$. hemerocallidis compared with the control at all collection times in the first trial, with the exception of fluoxastrobin at $48 \mathrm{~h}$ (82.4\% of control; Fig. 4A). No significant differences were observed for azoxystrobin at the 48- and 96-h and fluoxastrobin at the 96-h collection time compared with the control in the second trial (Fig. 4B). Cumulative urediniospore production of $P$. hemerocallidis was significantly lower for the four QoI fungicides compared with the control in both trials (Fig. 4B and D). Urediniospore production was lower with the pyraclostrobin treatment (31.5\% of control) compared with azoxystrobin $(61.3 \%$ of control) and fluoxastrobin (56.0\% of control) in the first trial (Fig.

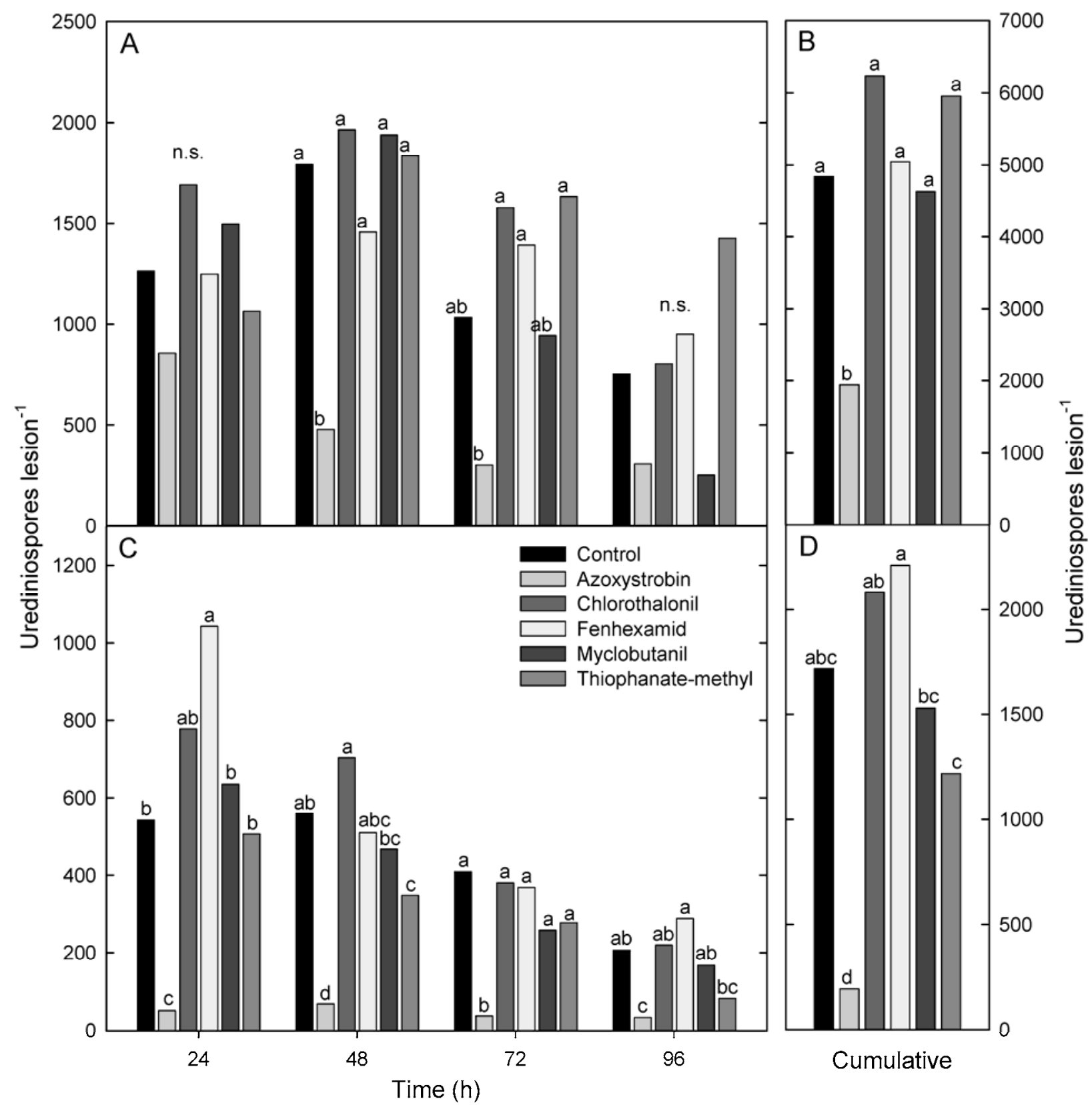

Fig. 1. Effect of azoxystrobin, chlorothalonil, fenhexamid, myclobutanil, or thiophanate-methyl on urediniospore production by Puccinia triticina on wheat. Data represent $\mathbf{A}$ and $\mathbf{C}$, the average number of urediniospores produced per lesion from five replicate plants at 24-h intervals or B and $\mathbf{D}$, total production over the $96-\mathrm{h}$ experiment for $\mathbf{A}$ and $\mathbf{B}$, trial 1 and $\mathbf{C}$ and $\mathbf{D}$, trial 2. Mean separation letters indicate significant differences at $P=0.05$ (Fisher's protected least significant difference) within each 24-h time interval and for cumulative production. N.S. not significant. 
4A), and lower than azoxystrobin, fluoxastrobin, and trifloxystrobin in the second trial (Fig. 4B).

\section{Discussion}

Postsymptom application of QoI fungicides significantly reduced urediniospore production in the two rust pathosystems used in the present study: $P$. triticina on wheat and $P$. hemerocallidis on daylily. Significant reductions in urediniospore production were observed $24 \mathrm{~h}$ after the fungicide treatments, suggesting that sufficient active ingredient had moved from the leaf surface to the underlying fungal tissues and was impacting spore production. Indeed, plant uptake of QoI fungicides is a gradual process, with up to 25 and 30 to $45 \%$ of material applied to the leaf surface absorbed into the underlying cells within $24 \mathrm{~h}$ for azoxystrobin and picoxystrobin, respectively (3). Similarly, after a 4-day period, $30 \%$ of the QoI fungicide kresoxim-methyl had penetrated the leaf surface (12). Not all fungicides affected urediniospore production; application of the broad-spectrum chlorothalonil fungicide or the benzimidazole thiophanate- methyl did not have any effect on urediniospore production in either pathosystem.

The overall reduction in urediniospore production by azoxystrobin ranged from 35.6 to $61.3 \%$ of the control for P. hemerocallidis and 11.3 to $40.1 \%$ for P. triticina. The largest reductions in urediniospore production in these experiments on wheat are similar to those obtained for $P$. graminis on ryegrass (24). The larger reductions in urediniospore production by $P$. triticina compared with $P$. hemerocallidis could be due to differences in leaf morphology of the respective hosts. Uptake of azoxystrobin is affected by leaf type and leaf surface characteristics (3). The thinner, less waxy wheat leaves may have allowed for a more rapid uptake of the active ingredients and increased effect on urediniospore production on wheat compared with daylily.

Pyraclostrobin and azoxystrobin are methoxy carbamate and methyl-acrylate QoIs, respectively (FRAC Code List 2011). Compared with azoxystrobin, pyraclostrobin has relatively low translaminar movement (3), which would suggest that a greater fungicidal or fungistatic effect would be observed with azoxystrobin and

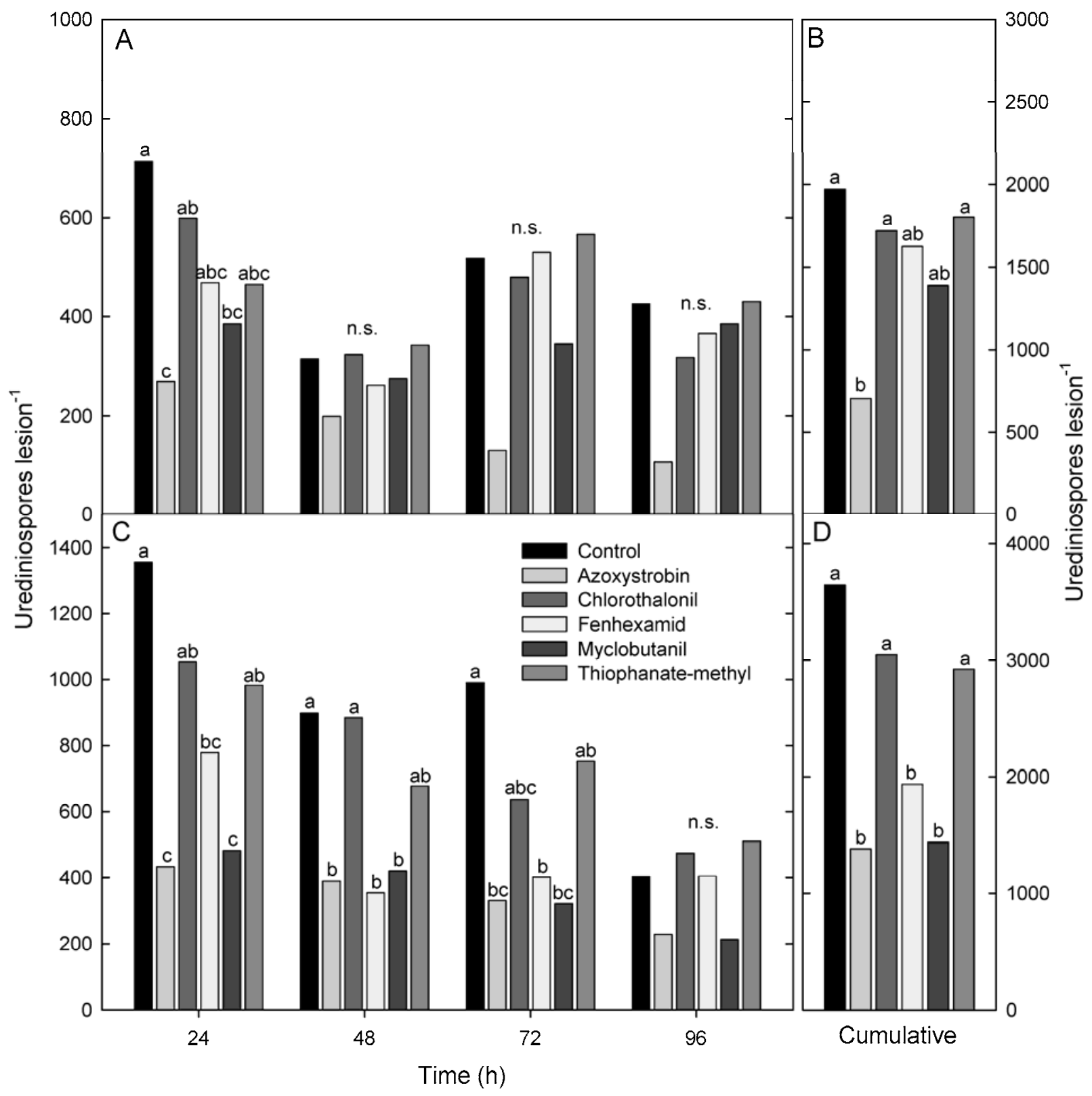

Fig. 2. Effect of azoxystrobin, chlorothalonil, fenhexamid, myclobutanil or thiophanate-methyl, on urediniospore production by Puccinia hemerocallidis on daylily. Data represent $\mathbf{A}$ and $\mathbf{C}$, the average number of urediniospores produced per lesion from four replicate plants at 24-h intervals or $\mathbf{B}$ and $\mathbf{D}$, total production over the 96-h experiment for $\mathbf{A}$ and $\mathbf{B}$, trial 1 and $\mathbf{C}$ and $\mathbf{D}$, trial 2. Mean separation letters indicate significant differences at $P=0.05$ (Fisher's protected least significant difference) within each 24-h time interval and for cumulative production. N.S. not significant. 
not pyraclostrobin. However, cumulative urediniospore production of $P$. hemerocallidis was significantly lower with the pyraclostrobin treatment compared with azoxystrobin; an effect that was not observed with $P$. triticina on wheat. It is unclear why this occurred. A differential effect on rust biology, such as urediniospore production or lesion development, due to systemic movement of the QoIs could be more apparent on new plant growth not directly treated with fungicide. For example, unsprayed leaves of daylily had significantly fewer $P$. hemerocallidis lesions compared with control plants when sprayed with azoxystrobin 5 days prior to inoculation, showing movement of the active ingredient (20). We suggest that such lesions would also produce fewer urediniospores.

Significant reductions in urediniospore production by $P$. hemerocallidis were observed with myclobutanil on daylily but no effect was observed against $P$. triticina on wheat. This may be due to differences in sensitivity to myclobutanil between the two species of fungi. Myclobutanil is labeled for use on ornamental plants (e.g., Eagle, Spectracide Immunox) but is not used as a foliar fungicide on wheat. Other triazole fungicides such as propiconazole and tebuconazole are labeled for wheat rust (e.g., Folicur, Stratego) and propiconazole significantly reduced urediniospore production by $P$. graminis on perennial ryegrass (24). Triazole chemistries act on mycelial growth and colonization, inhibiting fungal cell membrane development by preventing ergosterol biosynthesis (17). Myclobutanil has been reported as a curative agent against $P$. horiana on chrysanthemum (8). Pustules sprayed with myclobutanil 10, 15, and 20 days after inoculation were also observed to produce few sporidia, and the authors concluded they would contribute little to disease spread. Myclobutanil was also shown to be fungistatic to urediniospores of six rust fungi, including $P$. hemerocallidis, with urediniospore germination less than $5 \%$

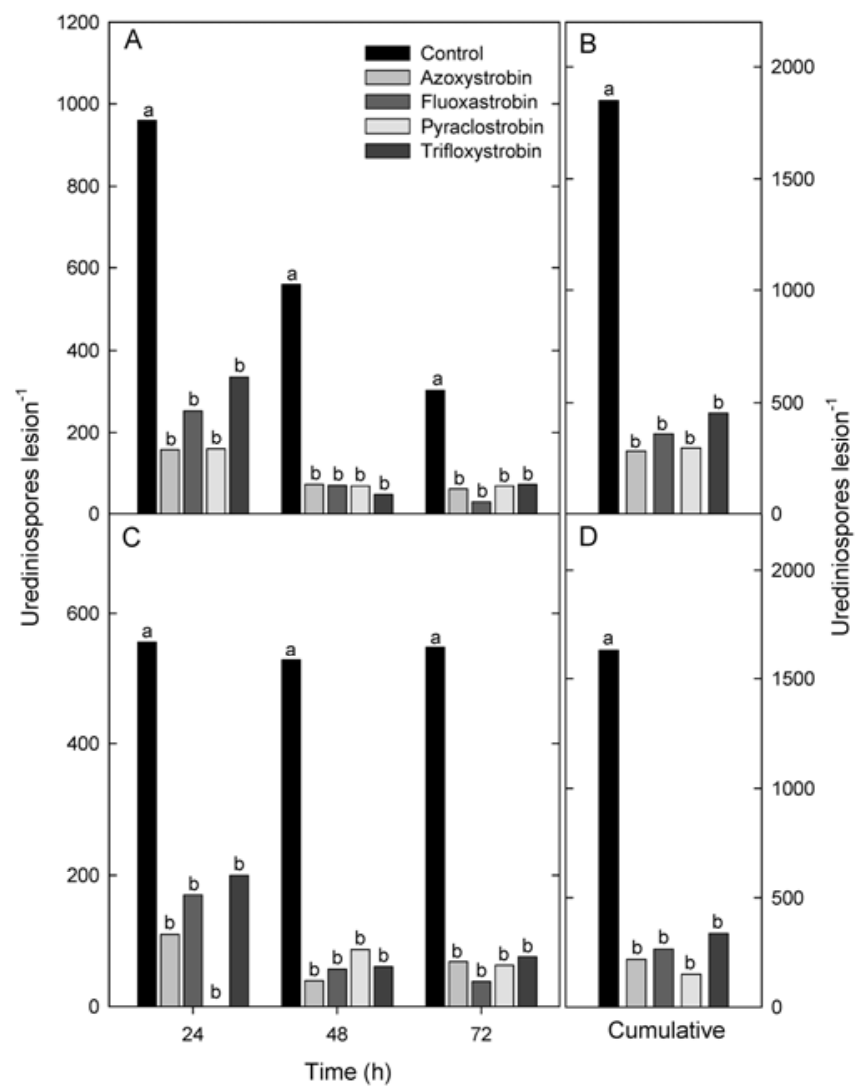

Fig. 3. Effect of azoxystrobin, fluoxystrobin, pyraclostrobin, or trifloxystrobin on urediniospore production by Puccinia triticina on wheat. Data represent $\mathbf{A}$ and $\mathbf{C}$, the average number of urediniospores produced per lesion from five replicate plants at 24-h intervals or $\mathbf{B}$ and $\mathbf{D}$, total production over the 72-h experiment for $\mathbf{A}$ and $\mathbf{B}$, trial 1 and $\mathbf{C}$ and $\mathbf{D}$, trial 2. Mean separation letters indicate significant differences at $P=0.05$ (Fisher's protected least significant difference) within each 24-h time interval and for cumulative production. of controls when the spores were exposed to the active ingredient (21).

A significant reduction in the production of urediniospores would negatively impact spread of inoculum both within an infected plant and from plant to plant (24). We evaluated urediniospore production 3 to 4 days post treatment to mature, sporulating lesions. Pfender (24) also observed a dramatic reduction in urediniospore production 4 days post treatment. The negative effect on urediniospore production by the QoI fungicides should continue as long as there is a sufficient concentration of active ingredient within the plant cells to have a biological effect. Azoxystrobin is a very effective fungicide against rusts, with a significant effect on lesion development observed when plants were treated 14 or 15 days in advance of inoculation $(20,22,24)$ and 7 days (22) and 15 days (24) postinfection. We observed a significant reduction in disease development by $P$. hemerocallidis on daylily with applications of pyraclostrobin 3 weeks prior to inoculations (7). Presumably, the negative effect on urediniospore production would continue at least 2 weeks post treatment to sporulating lesions and perhaps much longer. Sundin et al. (31) observed reductions in urediniospore production by $P$. recondita of $50 \%$ for at least 6 weeks due to seed treatments with the triazole fungicides difenoconazole or triadimenol.

The significant reduction in sporulation in the two rust fungi in the current study supports the conclusion of Pfender (24) that postsymptom application of QoI fungicides would dramatically reduce inoculum spread and additional disease development. Currently, QoI fungicides are recommended for use on rust diseases once symptoms are present only when combined with an appropriate non-QoI fungicide (e.g., Headline 2010 label; a.i. pyraclostrobin) to reduce the potential for resistance to develop in the target populations. However, despite the extensive worldwide use of QoI fungicides on multiple crops against rust fungi, widespread resistance problems have not developed (10). Resistance to QoIs has

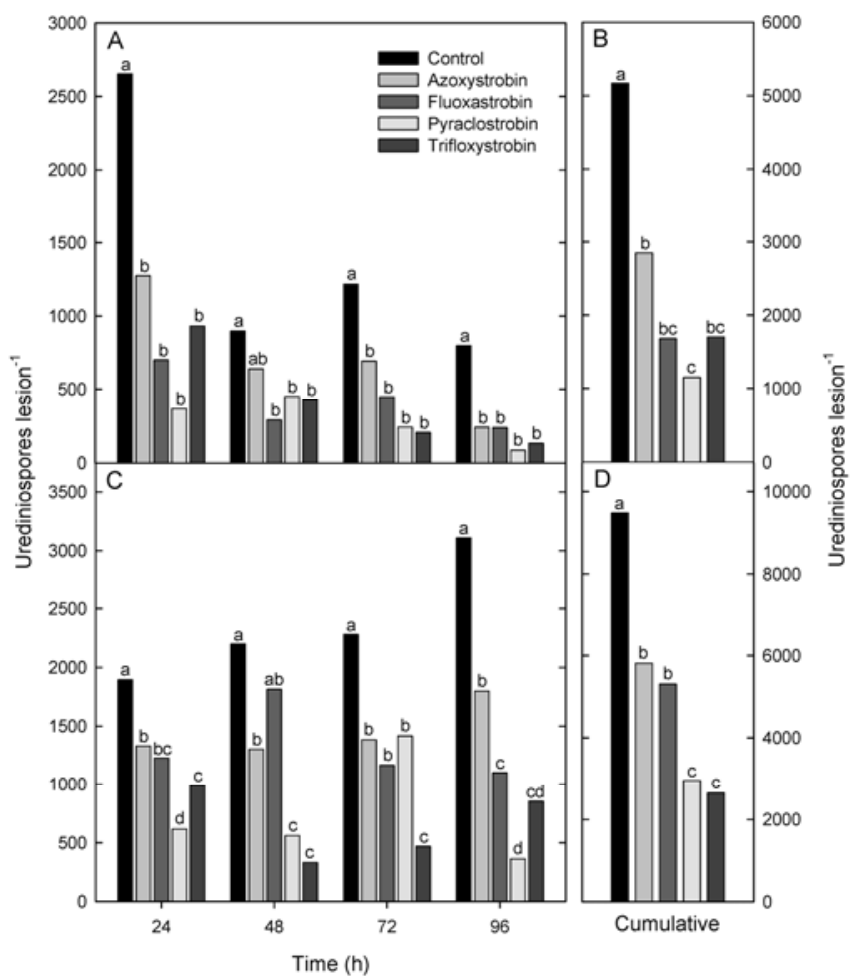

Fig. 4. Effect of azoxystrobin, fluoxystrobin, pyraclostrobin, or trifloxystrobin on urediniospore production by Puccinia hemerocallidis on daylily. Data represent $\mathbf{A}$ and $\mathbf{C}$, the average number of urediniospores produced per lesion from four replicate plants at $24-h$ intervals or $\mathbf{B}$ and $\mathbf{D}$, total production over the $96-\mathrm{h}$ experiment for $\mathbf{A}$ and $\mathbf{B}$, trial 1 and $\mathbf{C}$ and $\mathbf{D}$, trial 2. Mean separation letters indicate significant differences at $P=0.05$ (Fisher's protected least significant difference) within each 24-h time interval and for cumulative production. 
been documented with one isolate of $P$. horiana; however, it was not due to a point mutation in the cytochrome $b$ gene as with nonbasidiomyetous fungi but is attributed to alternative mechanisms (14). Although the best use of a fungicide is through preventative applications, applications of QoI fungicides to symptomatic (i.e., sporulating lesions) plants with rust pathogens of economic and quarantine significance such as $P$. polysora in corn and $P$. transversalis on gladiolus (33) should dramatically reduce urediniospore production and subsequent spread of the fungus to noninfested plants. This would help to prevent yield loss in crops, and ensure the success of federally mandated quarantine and eradication programs for regulated rust fungi.

\section{Literature Cited}

1. Anesiadis, T., Karaoglanidis, G. S., and Tzavella-Klonari, K. 2003. Protective, curative and eradicant activity of the strobilurin fungicide azoxystrobin against Cercospora beticola and Erysiphe betae. J. Phytopathol. 151:647651.

2. Balba, H. 2007. Review of strobilurin fungicide chemicals. J. Environ. Sci. Health 4:441-451.

3. Bartlett, D. W., Clough, J. M., Godwin, J. R., Hall, A. A., Hamer, M., and Parr-Dobrzanski, B. 2002. The strobilurins fungicides. Pest. Manage. Sci. 58:649-662.

4. Buck, J. W. 2007. Potential risk of commercial geranium to infection by Puccinia pelargonii-zonalis. Online. Plant Health Progress doi:10.1094/ PHP-2007-1031-02-RS.

5. Buck, J. W., Dong, W., and Mueller, D. S. 2010. Effect of light exposure on in vitro germination and germ tube growth of eight species of rust fungi. Mycologia 102:1134-1140.

6. Buck, J. W., and Williams-Woodward, J. L. 2003. The effect of fungicides on urediniospore germination and disease development of daylily rust. Crop Prot. 22:135-140.

7. Buck, J. W., and Youmans, J. 2009. Management of daylily rust with Insignia, Pageant or Trinity, 2007. Plant Dis. Man. Rep. 3:OT017. Online publication. doi:10.1094/PDMR03

8. Bonde, M. R., Peterson, G. L., Rizvi, S. A., and Smilanick, J. L. 1995. Myclobutanil as a curative agent for chrysanthemum white rust. Plant Dis. 79:500-505.

9. Dolezal, W., Kemerait, R., Kichler, J., Sapp, P., and Pataky, J. 2009. Unusual occurrence of southern rust, caused by Rpp 9 -virulent Puccinia polysora, on corn in southwestern Georgia. Plant Dis. 93:676.

10. Fernández-Ortu o, D., Torés, J. A., de Vicente, A., and Pérez-García, A. 2008. Mechanisms of resistance to QoI fungicides in phytopathogenic fungi. Int. Microbiol. 11:1-9.

11. Godwin, J. R., Anthony, V. M., Clough, J. M., and Godfrey, C. R. A. 1992. ICIA 5504: a novel, broad spectrum, systemic $\beta$-methoxyacrylate fungicide. Pages 435-442 in: Brighton Crop Prot. Conf. Pests Dis. Vol. 1. Lavenham Press, Lavenham, Suffolk, UK.

12. Gold, R. E., Ammerman, E., Koehle, H., Leinhos, G. M. E., Lorenz, G., Speakman, J. B., Stark-Urnau, M., and Sauter, H. 1996. The synthetic strobilurin BAS 490F: profile of a modern fungicide. Pages 79-92 in: Modern Fungicides and Antifungal Compounds. H. Lyr, P. E. Russell, and H. D. Sisler, eds. Intercept, Andover, Hants, UK.

13. Gold, R. E., and Leinhos, G. M. 1995. Fungicidal effects of BAS490F on the development and fine structure of plant pathogenic fungi. Pestic. Sci. 43:250-253.

14. Grasso, V., Siertotzki, H., Garibaldi, A., and Gisi, U. 2006. Characterization of the cytochrome $\mathrm{b}$ gene fragment of Puccinia species responsible for the binding site of QoI fungicides. Pestic. Biochem. Physiol. 84:72-82.

15. Hartman, G. L., Miles, M. R., and Frederick, R. D. 2005. Breeding for resistance to soybean rust. Plant Dis. 89:664-666.

16. Johnson, D. A., Cummings, T. F., and Geary, B. 2000. Postinfection activity of selected late blight fungicides. Plant Dis. 84:1116-1120.

17. Köller, W. 1992. Antifungal agents with target site in sterol functions and biosynthesis. Pages 119-206 in: Target Sites of Fungicide Action. W. Koller, ed. CRC Press, Boca Raton, FL.

18. Kolmer, J. A. 2005. Tracking wheat rust on a continental scale. Curr. Opin. Plant Biol. 8:441-449.

19. Leroux, P. 1996. Recent developments in the mode of action of fungicides. Pestic. Sci. 47:191-197.

20. Mueller, D. S., Jeffers, S. N., and Buck, J. W. 2004. Effect of timing of fungicide applications on development of rusts on daylily, geranium, and sunflower. Plant Dis. 88:657-661.

21. Mueller, D. S., Jeffers, S. N., and Buck, J. W. 2005. Toxicity of fungicides to urediniospores of six rust fungi that occur on ornamental crops. Plant Dis. 89:255-261.

22. Mueller, D. S., Martinez-Espinoza, A. D., and Buck, J. W. 2004. Evaluation of fungicides for management of geranium rust, 2003. Fungic. Nematicide Tests 59:OT034. Online publication. doi: 10.1094/FN59.

23. Mueller, D. S., Williams-Woodward, J. L., and Buck, J. W. 2003. Resistance of daylily cultivars to the daylily rust pathogen, Puccinia hemerocallidis. HortScience 38:1137-1140.

24. Pfender, W. F. 2006. Interaction of fungicide physical modes of action and plant phenology in control of stem rust of perennial ryegrass grown for seed. Plant Dis. 90:1225-1232.

25. Pretorius, Z. A., Singh, R. P., Wagoire, W. W., and Payne, T. S. 2000. Detection of virulence to wheat stem rust resistance Gene Sr31 in Puccinia graminis f. sp. tritici in Uganda. Plant Dis. 84:203.

26. Reis, R. F., de Goes, A., Mondal, S. N., Shilts, T., Brentu, F. C., and Timmer. L. W. 2006. Effect of lesion age, humidity, and fungicide application on sporulation of Alternaria alternata, the cause of brown spot of tangerine. Plant Dis. 90:1051-1054.

27. Reuveni, M. 2001. Activity of trifloxystrobin against powdery mildew and downy mildew diseases of grapevines. Can. J. Plant Pathol. 23:52-29.

28. Roelfs, A. P., Singh, R. P., and Saari, E. E. 1992. Rust Diseases of Wheat: Concepts and Methods of Disease Management. CIMMYT, Mexico, DF.

29. Saari, E. E., and Prescott, J. M. 1985. World distribution in relation to economic losses. Pages 259-298 in: The Cereal Rusts, Vol. 2. A. P. Roelfs and W. R. Bushnell, eds. Academic Press, Orlando, FL.

30. Stark-Urnau, M., Gold, R., Guggenheim, R., and Duggelin, M. 1997. Sensitivity of different mildew and rust fungi against kresoxim-methyl. Pages 268-271 in: Proc. Eur. Mediterr. Cereal Rusts of Powdery Mildews Conf. 9th. Lunteren, The Netherlands.

31. Sundin, D. R., Bockus, W. W., and Eversmeyer, M. G. 1999. Triazole seed treatments suppress spore production by Puccinia recondita, Septoria tritici, and Stagonospora nodorum from wheat leaves. Plant Dis. 83:328332 .

32. Williams-Woodward, J. L., Hennen, J. F., Parda, K. W., and Fowler, J. M. 2001. First report of daylily rust in the United States. Plant Dis. 85:1121.

33. Wise, K. A., Mueller, D. S., and Buck, J. W. 2004. Quarantines and ornamental rusts. APSnet feature article, February. http://www.apsnet.org/ publications/apsnetfeatures/Documents/2004/QuarantinesOrnamentalRusts. pdf

34. Wong, F. P., and Wilcox, W. F. 2001. Comparative physical modes of action of azoxystrobin, mancozeb and metalaxyl against Plasmopara viticola. Plant Dis. 85:649-656. 